\title{
Isolation and Characterisation of Thermophilic Bacillus licheniformis SUNGC2 as Producer of $\alpha$-Amylase from Malaysian Hot Spring
}

\author{
Marwan Jawad Msarah ${ }^{1,2}$, Ayesha Firdose ${ }^{1}$, Izyanti Ibrahim ${ }^{1}$ and \\ Wan Syaidatul Aqma ${ }^{1 *}$ \\ ${ }^{1}$ Department of Biological Sciences \& Biotechnology, Faculty of Science and Technology, Universiti \\ Kebangsaan Malaysia, 43600, Bangi, Selangor \\ ${ }^{2}$ Department of Radiology Technologies, Al-Hadi University, 10022, Baghdad, Iraq
}

\begin{abstract}
Screening of new source of novel and industrially useful enzymes is a key research pursuit in enzyme biotechnology. The study aims to report the characteristics of novel thermophilic microorganisms isolated from Sungai Klah (SK) Hot Spring, Perak, Malaysia, that can produce $\alpha$-amylase. The morphological and biochemical properties were examined for SUNGC2 sample. The isolate was further screened for amylase, followed by $16 \mathrm{~S}$ rRNA and analytical profile index (API) test. This isolate was further subjected to $\mathrm{pH}$ optimisation for $\alpha$-amylase production. It was found that SUNGC2 was an $\alpha$-amylase producer and was identified as Bacillus licheniformis SUNGC2 with NCBI accession numbers MH062901. The enzyme was found to exhibit an optimum temperature of $50^{\circ} \mathrm{C}$ and a $\mathrm{pH}$ of 7.0. The relative activity of the enzyme was obtained based on the improvement of the culture conditions. The highest amount of amylase production was $24.65 \mathrm{U} / \mathrm{mL}$ at $\mathrm{pH} 7.0$, consecutively the growth was also highest at $\mathrm{pH} 7.0$ with a 9.45 -fold increase in specific activity by ammonium phosphate precipitation of $80 \%(\mathrm{w} / \mathrm{v})$. The results showed that the bacteria isolated from the hot spring are a significant source of thermophilic enzymes that are highly promising in biotechnology.
\end{abstract}

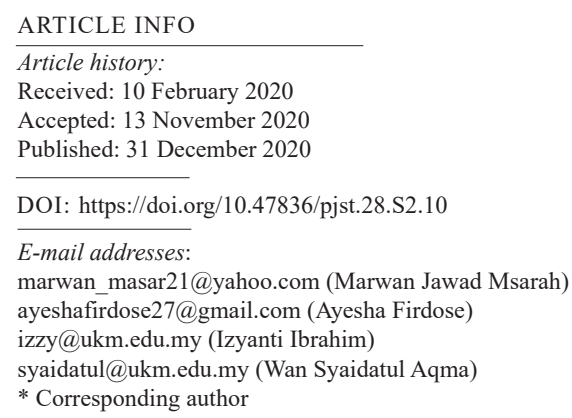

Keywords: Alpha amylase, bacillus licheniformis, thermophilic, hot spring

\section{INTRODUCTION}

The thermophilic Bacillus can be isolated from different extreme environments including thermal hot-springs, shallow vents and deep sea hydrothermal with optimum growth temperatures range between $45^{\circ} \mathrm{C}$ 
and $70^{\circ} \mathrm{C}$ (Adiguzel et al., 2009). Thermophilic bacilli enzymes can be produced in enormous quantities employing a comparatively less complicated purifying method that is highly beneficial compared to those from mesophilic or psychrophilic bacteria (Burgess et al., 2010). Currently, the screening for a new source of novel and beneficial enzymes for biotech industries is in great demand. Novel enzymes ought to have the benefit of being stable at high temperatures, wide $\mathrm{pH}$ range, different concentrations of salts, solvents and also possess a variety of uses in industrial processes. The advantages of using thermophilic enzymes are well documented as industrial catalysts with the potential revenue reflected on the rapid growth of the enzymes market (Burgess et al., 2010; Van Der Maarel et al., 2002). Generally, the extracellular enzymes are more stable at various ranges of temperature and $\mathrm{pH}$, and easier to be isolated and purified compared to the intracellular enzymes (Teodoro \& Martins 2000).

The operation of biotechnological techniques at high thermal levels offers several benefits, and one example is temperature increase has a considerable effect on the solubility and bioavailability of organic compounds (Ameri et al., 2015). Consequently, several thermo-active amylases have been isolated and characterised, such as from Bacillus sp. (Ardhi et al., 2020), and Bacillus licheniformis ATCC 9945a (Božić et al., 2011). Amylase enzymes ( $\alpha$-amylase, $\beta$-amylase, and $\gamma$-amylase) are essential enzymes in current biotechnology and makeup approximately $30 \%$ of the global production of enzymes alternating from the process of converting starch to sugar syrups, to producing cyclo-dextrins specifically for pharmaceutics (Van Der Maarel et al., 2002). $\alpha$-amylases are universally allocated all through animals, flora and microbial kingdoms. The production of amylases is economically viable due to the microbial enzyme's ability to be manipulated to obtain enzymes of desired characteristics (Teodoro \& Martins 2000). $\alpha$-Amylases cleave $\alpha-1,4$-glycosidic bonds of carbohydrates and oligosaccharides. Therefore, they are used for industrial starch liquefaction and saccharification (Chai et al., 2016). The amylase family of enzymes is very important because of its versatility as potential industrial applications and among bacteria, B. licheniformis, B. subtilis, B. stearothermophilus and B. amyloliquefaciens have been extensively commercialised and applied for the production of the enzymes for different uses (Deljou \& Arezi 2016; Vidyalakshmi et al., 2009). Their applications in biotechnology include starch processing, biofuel, food, paper, textile and detergent industries, bioremediation of environmental pollutants and in clinical and medical applications. Industrial production of enzymes requires high productivity and in certain condition, the application of wild-type strains are not suitable for enzyme production (Jujjavarapu \& Dhagat 2019). The properties of $\alpha$-amylases such as thermostability and $\mathrm{pH}$ profile should match its application. Therefore, the diversity of the applications creates the need to search for novel $\alpha$ - amylases with advanced and enriched properties (Panosyan et al., 2020). The raw starch degrading amylases ideal for use in industry as well as for their attractive production cost-effectiveness (Mohammad et al., 2017). 
Hot springs are promising environments for thermophilic microorganisms and in the past few decades, hot springs globally have proven to be significant targets to isolate new thermotolerant or thermophilic microorganisms as a source for the production of thermozymes that offer significant stability (Verma et al., 2014). Malaysia has a significant number of hot springs, especially along the edge of the Banjaran Titiwangsa mountain range (Samsudin et al., 1997). The Sungai Klah (SK) Hot Spring, Perak ranks as the second hottest geothermal spring in the country. It has increased in attractiveness as it is considered a natural biomass degrading bioreactor because of the existence of an underwater vegetation bed (Chan et al., 2015; Lee et al., 2018). Biological studies of the Malaysian hot springs are limited due to the lack of complete information on their microbial communities (Chan et al., 2017). Nonetheless, (SK) Hot Spring has an abundant and varied phylogenetic population of thermophiles and a source with potential to isolate bacteria capable of producing amylase. This is due to its natural environment, high total organic carbon (TOC), plant litter shallow stream and geochemical parameters and a wide range of temperature and pH (Chan et al., 2017; Msarah et al., 2018). Nevertheless, no persistent research has focused on further utilisation of these thermophiles. The current study aims at amylolytic screening, isolation and characterisation of new thermophilic microorganisms isolated from Sungai Klah Hot Spring, that can possess high biotechnological and environmental potential, and as a continuous line of research for thermophilic bacteria acquired from hot springs in Malaysia.

\section{MATERIALS AND METHODS}

\section{Isolation, Cultivation and Qualitative Screening of $\alpha$-Amylase Producer Bacteria}

The strains used in this study have been isolated from Sungai Klah Hot Spring, Perak, Malaysia. The 23 samples isolated were then serially diluted from $10^{-1}$ to $10^{-6}$ with sterile distilled water and spread on nutrient agar (NA) plates. The inoculated plates were incubated at $50^{\circ} \mathrm{C}$ for three days with morphological observation of the culture. The shape, size, colour, elevation and margin of the colonies were identified and the pure colonies were streaked on a NA containing 1\% starch (Starch NA), incubated and observed for 36 hours at $50^{\circ} \mathrm{C}$. Single colonies confirm as amylase production by forming clear hydrolysis zones after a $0.5 \%(\mathrm{w} / \mathrm{v})$ iodine solution was dispensed over the isolates.

\section{Identification, DNA Sequencing and Phylogenetic Analysis}

Bacterial isolates were investigated for its physiological, cultural, morphological and biochemical characteristics (Harley \& Prescott 2005). Biochemical tests for the identification of thermophilic isolates including the production of indole, catalase, citrate and oxidase, urease test, and nitrate reduction were carried out. Colony grown on NA was used for the determination of colony morphologies. The growth temperature range was confirmed through incubation of the isolate at $30,40,50,60$ and $70^{\circ} \mathrm{C}$. Bacterial growth 
on $\mathrm{NaCl}(1 \%$ to $7 \%(\mathrm{w} / \mathrm{v}))$ and on blood agar were also observed. Further, isolates were identified using Analytical Profiling Index (API) strip tests according to the manufacturer's instructions for API 50 CHB and API20E strips (bioMérieux, SA, Marcy-l'Etoile, France). Bacterial suspension $(100 \mu \mathrm{L})$ was inoculated into the strips and incubated in a temperature ranged from $50-55^{\circ} \mathrm{C}$ for 48 hours. The pattern of the reactions obtained was coded into a numerical profile.

16S rRNA gene sequence analysis was conducted to confirm the identification of bacterial isolates. Amplification of the $16 \mathrm{~S}$ rRNA gene was carried out by polymerase chain reaction (PCR) with Prime Thermal Cycler (Techne ${ }^{\circledR} /$ Bibby Scientific, UK), using forward primer, 8-27 F, 5'-AGAGTTTGATCCTGGCTCAG-3' and reverse primer, 1492 R, 5'- GGTTACCTTGTTACGACT T-3'.

The bacterial genomic DNA of the isolates was subjected to purification employing the TE boil extraction method which is the modified protocol for bacterial DNA extraction (Li et al., 2003). Bacterial culture was grown in nutrient broth at $50^{\circ} \mathrm{C}$ for 18 hours. An appropriate number of bacterial cells was transferred to $1.5 \mathrm{~mL}$ micro-centrifuge tube and it was centrifuged for $1 \mathrm{~min}$ at $11200 \mathrm{x}$ g. The pellet was suspended in $200 \mu \mathrm{L}$ TE buffer [10 $\mathrm{mmol} / \mathrm{L}$ Tris- $\mathrm{HCl}$ ( $\mathrm{pH} \mathrm{8.0),} 1 \mathrm{mmol} / \mathrm{L}$ EDTA], and the mixture was briefly vortexed. The suspension was then put in a boiling water bath at $100^{\circ} \mathrm{C}$ for $1 \mathrm{~min}$, then freezed at $-70^{\circ} \mathrm{C}$ for $3 \mathrm{~min}$. The next step involved heating in boiling water bath at $100^{\circ} \mathrm{C}$ for $2 \mathrm{~min}$, freezing at $-70^{\circ} \mathrm{C}$ for $3 \mathrm{~min}$ (repeating for two times), then finally subjecting to centrifugation for $5 \mathrm{~min}$ at $11200 \mathrm{x}$ g. The supernatant $(100 \mu \mathrm{L})$ was placed into a sterile tube and kept at $-20^{\circ} \mathrm{C}$ for PCR. PCR was conducted using PROMEGA Go Taq ${ }^{\circledR} /$ USA Green Mix, $2 \mathrm{X}$. PCR protocol was subjected to heating up to the temperature of $94^{\circ} \mathrm{C}$ for $5 \mathrm{~min}$ for the initial DNA denaturation, and then by 30 cycles with the following cycling profile: $94^{\circ} \mathrm{C}$ for $1 \mathrm{~min}, 54^{\circ} \mathrm{C}$ for $1 \mathrm{~min}$, and $1.5 \mathrm{~min}$ at $72^{\circ} \mathrm{C}$ for annealing. A final extension step was conducted following the amplifying reaction for $5 \mathrm{~min}$ at a temperature of $72^{\circ} \mathrm{C}$. The range of identity for identifying bacteria employing the 16S rRNA gene analysis is $\leq 99 \%$ and $\geq 97 \%$ to the GenBank database and according to Drancourt et al. (2000) it permits distinguishing the strain at the genus level.

\section{Bacterial Isolate $\alpha$ - Amylase Production Medium}

Bacterial isolate was investigated for $\alpha$-amylase production on a medium $(\mathrm{g} / \mathrm{L}): \mathrm{NaCl}$ (0.1), soluble starch (10), magnesium sulphate $\mathrm{MgSO}_{4} \cdot 7 \mathrm{H}_{2} \mathrm{O}$ (1.0), disodium phosphate $\mathrm{Na}_{2} \mathrm{HPO}_{4}$ (3.0), peptone (2.0) and ferrous sulphate $\mathrm{FeSO}_{4}$ (0.03). Erlenmeyer flask (250 $\mathrm{mL})$ consisted of $1 \mathrm{~mL}$ inoculum $\left(1 \times 10^{8}\right.$ cells $\left./ \mathrm{mL}\right)$ mixed with $99 \mathrm{~mL}$ cultivation medium was incubated in an orbital shaker at $50^{\circ} \mathrm{C} / 48$ hours and agitated at $100 \mathrm{rpm}$. Filtration of the medium was done by using Whatman No.1 filter paper every 6 hours intervals. The cell free filtrate was employed for the $\alpha$-amylase assay and the bacterial growth was measured at $600 \mathrm{~nm}$ (Kumar \& Raja, 2019). The protein level was decided based on the approach 
described by Bradford (1976) at $595 \mathrm{~nm}$. The total protein was expressed as mg/mL. All experiments were carried out in triplicates in at least three different occasions.

\section{Amylase Assay}

The $\alpha$-amylase activity was carried out by using a modification of the di-nitro-salicylic acid (DNS) technique on the basis of the reducing sugars freed from the soluble starch and were determined by glucose standard curve (Miller, 1959). The standard curve was prepared by dissolving $100 \mathrm{mg}$ of glucose in $100 \mathrm{~mL}$ of distilled water and working standard was prepared by diluting $10 \mathrm{~mL}$ of stock solution to $100 \mathrm{~mL}$ with distilled water. The standard curve was prepared by taking $0,0.2,0.4,0.6,0.8$ and $1 \mathrm{~mL}$ of the working standard glucose solution and the final volume was made up to $1 \mathrm{~mL}$ by adding distilled water. One $\mathrm{mL}$ of glucose oxidase peroxidase reagent was added and the mixture was incubated at 35 ${ }^{\circ} \mathrm{C}$ for $40 \mathrm{~min}$. The reaction was terminated by the addition of $2 \mathrm{~mL}$ of $6 \mathrm{~N}-\mathrm{HCl}$, and the absorbance was recorded at a wavelength of $540 \mathrm{~nm}$ using Spectrophotometer. One $\mathrm{mL}$ soluble starch ( $1 \%$ soluble starch (w/v) in sodium citrate buffer $(0.05 \mathrm{M} / \mathrm{pH} 5.9)$ was heated in a water bath at $50^{\circ} \mathrm{C}$ for $10 \mathrm{~min}$. Then, $0.1 \mathrm{~mL}$ of crude enzyme was added to the substrate, followed by incubation at $50^{\circ} \mathrm{C}$ for $10 \mathrm{~min}$ through mild shaken. The reaction was halted by adding $2.0 \mathrm{~mL}$ of DNS reagent. The reaction mixture was then subjected to heat for $10 \mathrm{~min}$ at $100^{\circ} \mathrm{C}$, then allowed to cool to $27^{\circ} \mathrm{C}$ before dilution with distilled water $(16.9 \mathrm{~mL})$. Then the mixture measured by using UV-Visible spectrophotometer at $540 \mathrm{~nm}$ absorbance and the specific activity was then calculated and and reported in units per millilitre $(\mathrm{U} / \mathrm{mL})$. The enzyme acitivity is calculated by measuring umole of product formed (glucose) in 10 minutes assay by $0.1 \mathrm{~mL}$ enzyme sample (which will give umole/ $\mathrm{min} / \mathrm{mL}$ ) (Ibrahim et al., 2013).

\section{Optimisation of $\mathbf{p H}$}

The optimisation of culture conditions was evaluated with a variation of $\mathrm{pH}$ (ranging between 3.0, 7.0 and 9.0). The incubation temperature was set at $50^{\circ} \mathrm{C}$, the agitation speeds of $200 \mathrm{rpm}$, and the inoculum size of $0.5 \mathrm{McF}$ arland to increase amylase production by B. licheniformis SUNGC2. The medium was filtered using Whatman No.1 filter paper after 18 hours of cultivation and then the cell free filtrate used for the amylase assay. The mixture's absorbance was verified at $540 \mathrm{~nm}$ and bacterial growth was measured at 600 $\mathrm{nm}$ absorbance. All experiments were carried out in triplicates for at least three different occasions (Ardh et al., 2020).

\section{RESULTS AND DISCUSSION}

\section{Isolation of $\alpha$-Amylase Producing Bacteria}

The knowledge about thermophilic bacteria and the enzymes they produce from hot springs in Malaysia is significant and still moving forward in comparison with additional 
hot springs located worldwide (Chan et al., 2015, 2017; Msarah et al., 2018, 2020). In this study thermophilic $\alpha$-amylase producing bacteria were positively isolated from Sungai Klah Hot Spring in Perak, Malaysia. $\alpha$-Amylase activity was confirmed by the appearance of a clear surrounding (halo) of the colonies after staining with Lugol's iodine (Figure 1b). The qualitative screening of 23 isolates showed that isolate SUNGC2 produced the largest hydrolysis zone and therefore was selected for further optimisation process.

Enzyme production primarily linked to the growth of the microorganisms is called growth associated-enzymes, and according to Niu et al. (2009) and Asoodeh et al. (2010) some starch degrading enzymes such as $\alpha$-amylases are produced according to this mechanism. The results displayed that enzyme production was related to the growth of the isolate SUNGC2 $(0.261 \mathrm{mg} / \mathrm{mL})$ at 18 hours (Figure 2). SUNGC2 showed a decline

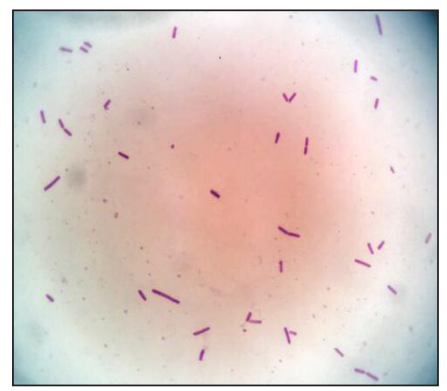

(a)

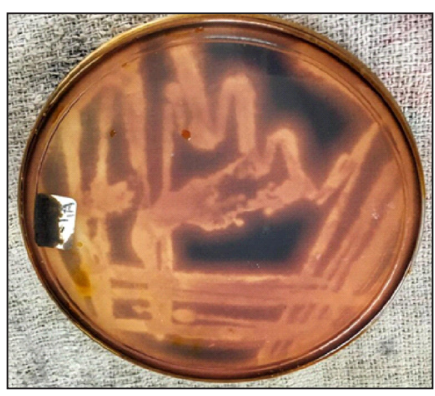

(b)

Figure 1. Microscope (a) and amylase qualitative screening (b) of B. licheniformis SUNGC2

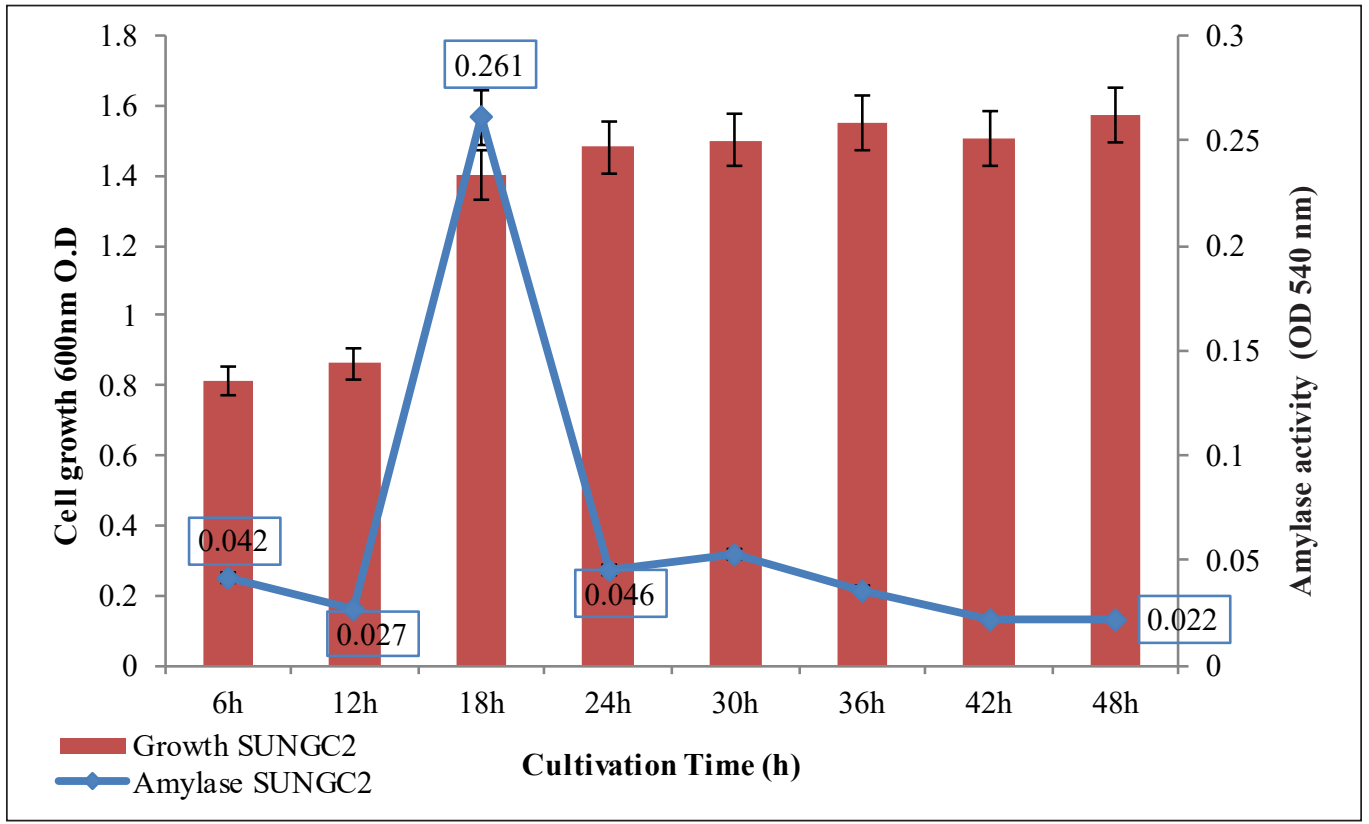

Figure 2. Amylase production and growth profile of B. licheniformis SUNGC2 
in amylase production after 18 hours until it reached $0.022 \mathrm{mg} / \mathrm{mL}$ at 48 hours, while the growth of SUNGC2 was increasing in log phase.

\section{Identification of $\alpha$-Amylase Producer Isolate SUNGC2}

SUNGC2 was identified based on its biochemical tests and microscopic characteristics. SUNGC2 was a Gram positive, rod-shaped bacterium, a pale colony in colour, flat elevation with irregular margins and producing distinctive scent. Additionally, the biochemical and cultural characteristics were also observed for further identification (Table 1). SUNGC2 showed positive results for the catalase production, nitrate reduction, citrate tests, grew well in $7 \%$ sodium chloride medium and positive beta hemolytic on blood agar. However, urease utilisation and indole tests showed negative results. It was observed that SUNGC2 grew at temperature of $55^{\circ} \mathrm{C}$. SUNGC2 was identified as a Bacillus sp. based on $16 \mathrm{~S}$ rRNA identification. The Bacillus sp. together with the thermophilic bacilli in general require uncomplicated nutritional requirements; hence, they have no requirement for any particular amino acids for growth and are able grow on enriched media like tryptone soya agar (TSA) or nutrient agar (NA) (Haki \& Rakshit 2003). Thermophilic Bacillus sp. possess an optimum growth temperature typically ranging from 50 to $70^{\circ} \mathrm{C}$ but differ among species and strains. They can be readily cultured and sub-cultured in the laboratory and utilised to extract useful compounds (Burgess et al., 2010).

Table 1

Microscopic, morphology and biochemical characteristics of $\mathrm{B}$. licheniformis SUNGC2

\begin{tabular}{llll}
\hline Characteristics & SUNGC2 & Biochemical tests & SUNGC2 \\
\hline Colony & Irregular & Indole production & Negative \\
Margin & Irregular & Catalase production & Positive \\
Elevation & Flat & Citrate production & Positive \\
Surface & Shiny and moist & Oxidase production & Negative \\
Color & Pale & Urease test & Negative \\
Odor & Yes & Nitrate reduction test & Positive \\
Growth & Aerobic and facultative & Growth at $55^{\circ} \mathrm{C}$ & Positive \\
& anaerobic growth & & \\
Gram staining & Positive & Hemolysis on the blood agar plate & $\beta$-hemolytic \\
The shape of vegetative & Rod-shaped & Growth in $7 \%$ sodium chloride & Positive \\
cells & & & \\
\hline
\end{tabular}

Gene analysis was achieved by using 16S rRNA amplification and 301 bases nucleotide sequence was obtained. Sequence then was analysed using Basic Local Alignment Search Tool (BLAST). The results showed 98\% similarity with Bacillus licheniformis. The sequences of SUNGC2 were stored in the GenBank database according to accession numbers of MH062901. The phylogenetic tree was built based on 16S rDNA sequence 
alignment employing Neighbor-Joining technique for the SUNGC2 strain (Figure 3). A total of 235 positions can be found in the final dataset. Evolutionary analyses were carried out via MEGA7 software (Kumar et al., 2016). Therefore, it was recommended that isolate SUNGC2 identified as B. licheniformis with the strain name of SUNGC2. Additional identification was then performed by API CHB50. SUNGC2 was identified by the API 50 CHB identification kit to provide additional details of the isolate's metabolic abilities.

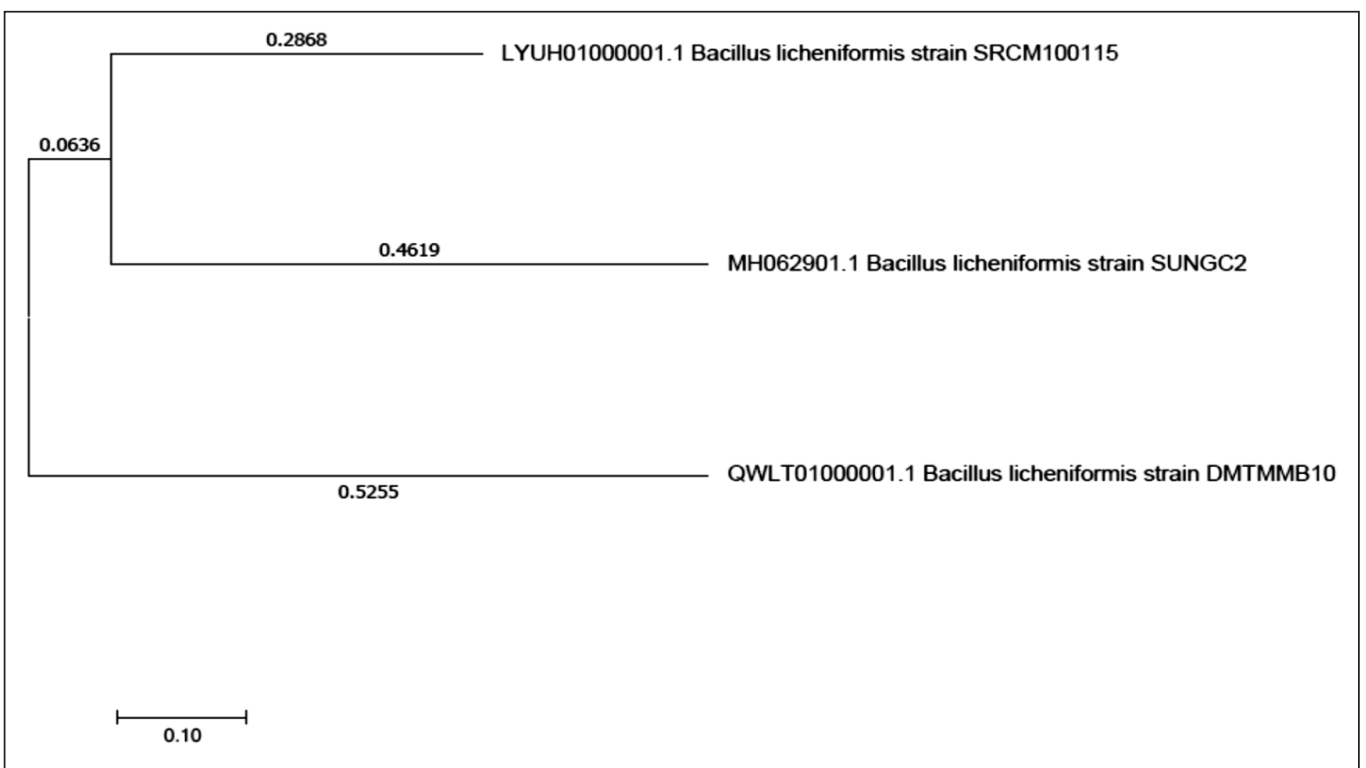

Figure 3. Evolutionary relationships of taxa for B. licheniformis SUNGC2

The outcomes are presented in Table 2 and Table 3. The isolate was identified as $B$. licheniformis according to the combination of partial 16S sequencing analysis and API 50CHB.

The API 50 CHB and API 20E result using apiweb ${ }^{\mathrm{TM}}$, showed a very good agreement with the previous results, that strain SUNGC2 is Bacillus licheniformis with \% ID of 99.3 homology.

Table 2

API50CH profile of $\mathrm{B}$. licheniformis $S U N G C 2$

\begin{tabular}{cccccc}
\hline Test No. & Substrate & SUNGC2 & Test No. & Substrate & SUNGC2 \\
\hline 0 & Control & - & 26 & Salicin & + \\
1 & Glycerol & + & 27 & D-Cellobiose & + \\
2 & Erythritol & + & 28 & D-Maltose & + \\
3 & D-arabinose & + & 28 & D-Lactose & + \\
4 & L-arabinose & + & 29 & D-Sucrose & - \\
5 & Ribose & + & 30 & Trehalose & - \\
\hline
\end{tabular}


Table 2 (continue)

\begin{tabular}{|c|c|c|c|c|c|}
\hline Test No. & Substrate & SUNGC2 & Test No. & Substrate & SUNGC2 \\
\hline 6 & D-xylose & + & 31 & Gentiobiose & + \\
\hline 7 & L-xylose & - & 32 & Melibiose & + \\
\hline 8 & Adonitol & - & 33 & Raffinose & + \\
\hline 9 & ß methyl-D-Xyloside & - & 34 & Melezitose & - \\
\hline 10 & Galactose & + & 35 & Starch & + \\
\hline 11 & Glucose & + & 36 & Glycogen & + \\
\hline 12 & Fructose & + & 37 & Inulin & + \\
\hline 13 & Mannose & + & 38 & D-Turanose & - \\
\hline 14 & L-Sorbose & - & 39 & D-Tagatose & + \\
\hline 15 & Rhamnose & + & 40 & D-Fucose & + \\
\hline 16 & Dulcitol & - & 41 & L-fucose & - \\
\hline 17 & Inositol & + & 42 & D-Lyxose & + \\
\hline 18 & Sorbitol & + & 43 & D-Arabitol & - \\
\hline 19 & Mannitol & + & 44 & L-Arabitol & - \\
\hline 20 & $\begin{array}{l}\text { L-Methyl-D- } \\
\text { mannoside }\end{array}$ & - & 45 & L-Sorbose & - \\
\hline 21 & D-Methyl-D-glucoside & + & 46 & Xylitol & - \\
\hline 22 & N-Acetylglucosamine & + & 47 & Gluconate & + \\
\hline 23 & Amygdalin & + & 48 & 2-Ketogluconate & - \\
\hline 24 & Arbutin & + & 49 & 5-Ketogluconate & - \\
\hline 25 & Aesculin & + & & & \\
\hline $\begin{array}{l}\text { Significant } \\
\text { taxa }\end{array}$ & Bacillus licheniformis & \% ID 99.3 & $\mathrm{~T}$ & & \\
\hline
\end{tabular}

+ , positive reaction; - negative reaction; ? non conclusive

Table 3

API 20 E profile of $\mathrm{B}$. licheniformis SUNGC2

\begin{tabular}{|c|c|c|c|c|c|c|c|c|c|c|c|c|c|c|c|}
\hline Strains code & \multicolumn{15}{|c|}{ API 20E } \\
\hline SUNGC2 & 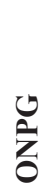 & 零 & ב & & ิ) & & $\stackrel{\infty}{=}$ & 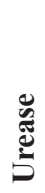 & $\overleftrightarrow{\theta}$ & $\frac{\stackrel{0}{巳}}{\stackrel{\theta}{\Xi}}$ & $\hat{>}$ & 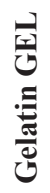 & 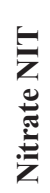 & 总 & 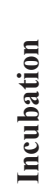 \\
\hline & + & & & - & - & $\begin{array}{l}+ \\
2\end{array}$ & - & - & - & - & + & $\begin{array}{l}+ \\
7\end{array}$ & + & $45 \mathrm{~h}$ & $\begin{array}{c}24 \\
\mathrm{~h}\end{array}$ \\
\hline
\end{tabular}

\section{pH Optimisation for $\alpha$-Amylase Production}

In our study, an additional rise in the $\mathrm{pH}$ level led to a reduction in the activity of $\alpha$-amylase as observed by Teodoro and Martins (2000). Figure 4, the amylase production was maximum at $\mathrm{pH} 7.0(24.65 \mathrm{U} / \mathrm{mL})$ and minimum at $\mathrm{pH} 9.0(7.65 \mathrm{U} / \mathrm{mL})$. The highest specific activity 
obtained by ammonium phosphate precipitation $80 \%$ (w/v) was $3.79 \mathrm{U} / \mu \mathrm{g}$ for SUNGC2 (9.45-fold increase). Various researches have mentioned that the optimisation of amylase production by Bacillus spp. is due to the specific enzyme conditions for each application (Hmidet et al., 2009). Commonly, the enhancement of the microbial production of enzymes involves the optimisation of environmental parameters such as temperature, $\mathrm{pH}$, and nutrients. Amylase stability is beneficial for various applications and the characterisation of enzymes is significantly important for industrial applications. In this study, the $\mathrm{pH}$ effects on amylase activity in a range of 3.0-9.0 and are represented in Figure 4.

Enzymes from thermophilic microorganisms have special characteristics such as high stability to changes in wide range of $\mathrm{pH}$ (Alrumman et al., 2018). Elkhalil and Gaffar (2011) reported that the $\mathrm{pH}$ activity profile of $\alpha$-amylase produced from $B$. acidocaldarius had an activity optimum at $\mathrm{pH}$ 6.0. Several researchers studied the production of $\alpha$-amylase from Bacillus sp. and found its maximum activity at pH between 5.0 and 6.5 (Ardhi et al., 2020; Deljou \& Arezi 2016; Teodoro \& Martins 2000). However, Thippeswamy et al. (2006) reported a $\mathrm{pH}$ of 6.5 as an optimum for $\alpha$-amylase activity. It was detected that the highest amylase activity occurred at $\mathrm{pH}$ 6.0. However, the highest bacterial growth occurred at $\mathrm{pH}$ 8.0 , suggesting that the bacteria need an alkaline environment to synthesise the enzymes and that synthesis was not growth dependent.

Similarly, the growth was highest at $\mathrm{pH} 7.0$ and had a proportional relationship to the amylase production. The amylase extracted from B. licheniformis SUNGC2 has wide-

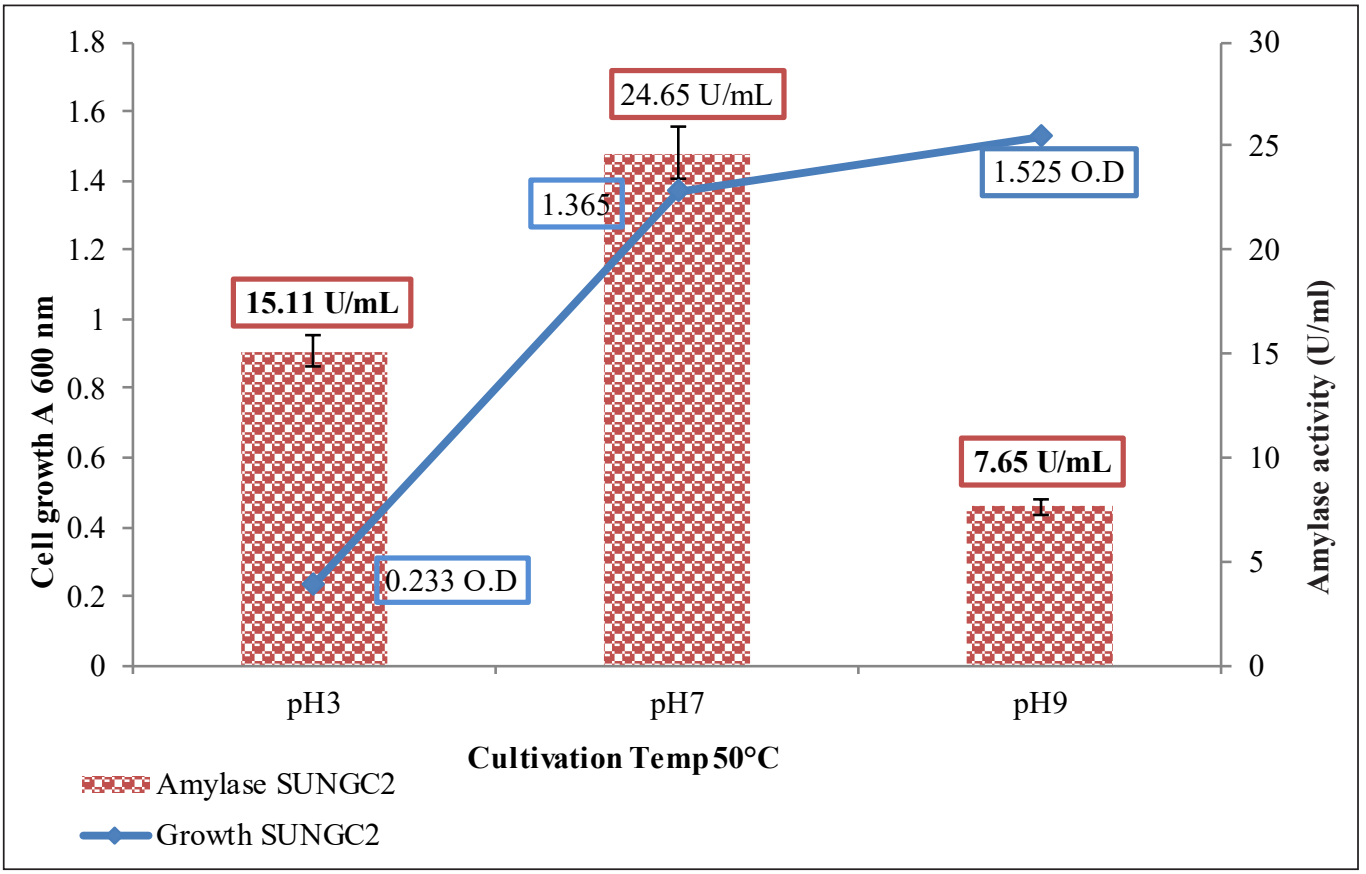

Figure 4. Effect of growth and $\mathrm{pH}$ on the enzyme activity of B. licheniformis SUNGC2 
ranging $\mathrm{pH}$ activity ( $\mathrm{pH}$ 3.0-9.0) with optimal $\mathrm{pH}$ at 7.0 which is close by to the optimum $\mathrm{pH}$ value of most Bacillus sp. amylase (Divakaran et al., 2011). The enzyme had about $30 \%$ relative activity at $\mathrm{pH} 9.0$ and about $50 \%$ at $\mathrm{pH} 3.0$. At $\mathrm{pH} 7.0$, the enzyme expressed $100 \%$ relative activity. According to the results, the amylase activity of $B$. licheniformis SUNGC2 was observed to be maximum at $\mathrm{pH} 7.0$ which in agreement to the findings by Oyeleke and Oduwole (2009) and Vidyalakshmi et al., (2009). Nevertheless, other research on amylase activity of $B$. licheniformis MIR 29 was found to be optimum at $\mathrm{pH}$ 9.0 (Ferrero et al., 2009).

\section{CONCLUSIONS}

The thermophilic B. licheniformis SUNGC2 was isolated and characterised from a Sungai Klah Hot Spring water samples from Perak, Malaysia. SUNGC2 was able to produce $\alpha$-amylase at $50^{\circ} \mathrm{C}$ and the growth and enzyme activity were showed to be optimum at $\mathrm{pH}$ 7.0. At 18 hours of cultivation at $\mathrm{pH} 7.0$, the $\alpha$-amylase activity was shown to be increased by 9.45 -fold compared to control. The results showed promising thermophilic microorganism $B$. licheniformis SUNGC2 capable of producing thermostable $\alpha$-amylase, with stability over wide-ranging $\mathrm{pH}$ which makes SUNGC2 a good candidate for various applications in biotechnology.

\section{ACKNOWLEDGEMENTS}

The authors acknowledge Universiti Kebangsaan Malaysia for financially supporting the project under Geran Universiti Penyelidikan (GUP-2018-112) and for the research facilities.

\section{REFERENCES}

Adiguzel, A., Ozkan, H., Baris, O., Inan, K., Gulluce, M., \& Sahin, F. (2009). Identification and characterisation of thermophilic bacteria isolated from hot springs in Turkey. Journal of Microbiological Methods, 79(3), 321-328. doi: 10.1016/j.mimet.2009.09.026

Alrumman, S., Mostafa, Y. S. M., Al-Qahtani, S., \& Taha, T. H. T. (2018). Hydrolytic enzyme production by thermophilic bacteria isolated from Saudi Hot Springs. Open Life Sciences 13(1), 470-480. doi: 10.1515/ biol-2018-0056

Ameri, A., Shakibaie, M., Amirpour-Rostami, S., Ameri, A., Adeli-Sardou, M., Khazaeli, P., ... \& Farootanfar, H. (2015). Partial purification and characterisation of a thermoalkalophilic lipase originated from Bacillus atrophaeus FSHM2 and its application for ester synthesis. Biotechnology, 14(4), 154-164. doi:10.3923/ biotech.2015.154.164

Ardhi, A., Sidauruk, A. N., Suraya, N., Pratiwi, N. W., \& Pato, U. (2020). Molecular identification of amylase-producing thermophilic bacteria isolated from Bukit Gadang Hot Spring, West Sumatra, Indonesia. Biodiversitas Journal of Biological Diversity, 21(3), 994-1000. doi:10.13057/biodiv/d210319 
Asoodeh, A., Chamani, J., \& Lagzian, M. (2010). A novel thermostable, acidophilic $\alpha$-amylase from a new thermophilic "Bacillus sp. Ferdowsicous" isolated from Ferdows hot mineral spring in Iran: Purification and biochemical characterisation. International Journal of Biological Macromolecules, 46(3), 289-297. doi:10.1016/j.ijbiomac.2010.01.013

Božić, N., Ruiz, J., López-Santín, J., \& Vujčić, Z. (2011). Production and properties of the highly efficient raw starch digesting $\alpha$-amylase from a Bacillus licheniformis ATCC 9945a. Biochemical Engineering Journal, 53(2), 203-209. doi:10.1016/j.bej.2010.10.014

Bradford, M. M. (1976). A rapid and sensitive method for the quantitation of microgram quantities of protein utilising the principle of protein-dye binding. Analytical Biochemistry, 72(1-2), 248-254. doi:10.1016/0003-2697(76)90527-3

Burgess, S. A., Lindsay, D., \& Flint, S. H. (2010). Thermophilic Bacilli and their importance in dairy processing. International Journal of Food Microbiology, 144(2), 215-225. doi:10.1016/j.ijfoodmicro.2010.09.027

Chan, C. S., Chan, K. G., Ee, R., Hong, K. W., Urbieta, M. S., Donati, E. R., .. \& \& Goh, K. M. (2017). Effects of physiochemical factors on prokaryotic biodiversity in Malaysian circumneutral hot springs. Frontiers in Microbiology, 8, 1-14. doi:10.3389/fmicb.2017.01252

Chan, C. S., Chan, K. G., Tay, Y. L., Chua, Y. H., \& Goh, K. M. (2015). Diversity of thermophiles in a Malaysian hot spring determined using 16S rRNA and shotgun metagenome sequencing. Frontiers in Microbiology, 6, 1-15. doi:10.3389/fmicb.2015.00177

Deljou, A., \& Arezi, I. (2016). Production of thermostable extracellular $\alpha$-amylase by a moderate thermophilic Bacillus licheniformis isolated from Qinarje Hot Spring (Ardebil prov. of Iran). Periodicum Biologorum, 118(4), 405-416. doi:10.18054/pb.v118i4.3737

Divakaran, D., Chandran, A., \& Pratap Chandran, R. (2011). Comparative study on production of $\alpha$-amylase from Bacillus licheniformis strains. Brazilian Journal of Microbiology, 42(4), 1397-1404. doi:10.1590/ s1517-83822011000400022

Drancourt, M., Bollet, C., Carlioz, A., Martelin, R., Gayral, J. P., \& Raoult, D. (2000). 16S ribosomal DNA sequence analysis of a large collection of environmental and clinical unidentifiable bacterial isolates. Journal of Clinical Microbiology, 38(10), 3623-3630. doi:10.1128/jcm.38.10.3623-3630.2000

Elkhalil, E. A., \& Gaffar, F. Y. (2011). Biochemical characterisation of thermophilic amylase enzyme isolated from Bacillus strains. International Journals of Science and Nature 2(3), 616-620.

Ferrero, M. A., Castro, G. R., Abate, C. M., Baigori, M. D., \& Sineriz, F. (1996). Thermostable alkaline proteases of Bacillus licheniformis MIR 29: Isolation, production and characterisation. Applied Microbiology and Biotechnology, 45(3), 327-332. doi:10.1007/s002530050691

Haki, G. D., \& Rakshit, S. K. (2003). Developments in industrially important thermostable enzymes: A review. Bioresource Technology, 89(1), 17-34. doi:10.1016/s0960-8524(03)00033-6

Harley, J. P., \& Prescott, L. M. (2005). Laboratory exercises in microbiology. New York: McGraw-Hill.

Hmidet, N., Ali, N. E. H., Haddar, A., Kanoun, S., Alya, S. K., \& Nasri, M. (2009). Alkaline proteases and thermostable $\alpha$-amylase co-produced by Bacillus licheniformis NH1: Characterisation and potential 
application as detergent additive. Biochemical Engineering Journal, 47(1-3), 71-79. doi:10.1016/j. bej.2009.07.005

Ibrahim, D., Zhu, H. L., \& Yusof, N. (2013). Bacillus licheniformis BT5. 9 isolated from Changar Hot spring, Malang, Indonesia, as a potential producer of thermostable $\alpha$-amylase. Tropical Life Sciences Research, 24(1), 71-84.

Jujjavarapu, S. E., \& Dhagat, S. (2019). Evolutionary trends in industrial production of $\alpha$-amylase. Recent Patents on Biotechnology, 13(1), 4-18. doi:10.2174/2211550107666180816093436

Kumar, R. M., \& Raja, S. S. (2019). Isolation, screening and identification of potential thermo stable bacterial enzyme producers in Sangameshwar, Tural Hot Spring. Journal of Drug Delivery and Therapeutics, 9(4), 510-517. doi:10.22270/jddt.v9i4.3094

Kumar, S., Stecher, G., \& Tamura, K. (2016). MEGA7: Molecular evolutionary genetics analysis version 7.0 for bigger datasets. Molecular Biology and Evolution, 33(7), 1870-1874. doi:10.1093/molbev/msw054

Lee, L. S., Goh, K. M., Chan, C. S., Annie Tan, G. Y., Yin, W. F., Chong, C. S., \& Chan, K. G. (2018). Microbial diversity of thermophiles with biomass deconstruction potential in a foliage rich hot spring. Microbiology Open, 7(6), 1-13. doi:10.1002/mbo3.615

Li, M., Gong, J., Cottrill, M., Yu, H., de Lange, C., Burton, J., \& Topp, E. (2003). Evaluation of QIAamp ${ }^{\circledR}$ DNA Stool Mini Kit for ecological studies of gut microbiota. Journal of Microbiological Methods, 54(1), 13-20. doi:10.1016/s0167-7012(02)00260-9

Miller, G. L. (1959). Use of dinitrosalicylic acid reagent for determination of reducing sugar. Analytical Chemistry, 31(3), 426-428. doi:10.1021/ac60147a030

Mohammad, B. T., Al Daghistani, H. I., Jaouani, A., Abdel-Latif, S., \& Kennes, C. (2017). Isolation and characterization of thermophilic bacteria from Jordanian hot springs: Bacillus licheniformis and Thermomonas hydrothermalis isolates as potential producers of thermostable enzymes. International Journal of Microbiology, 2017, 1-12. doi:10.1155/2017/6943952

Msarah, M. J., Ibrahim, I., Hamid, A. A., \& Aqma, W. S. (2020). Optimisation and production of alpha amylase from thermophilic Bacillus spp. and its application in food waste biodegradation. Heliyon, 6(6), e04183. doi:10.1016/j.heliyon.2020.e04183

Msarah, M., Ibrahim, I. \& Aqma, W.S. (2018). Enzyme activity screening of thermophilic bacteria isolated from Dusun Tua Hot Spring. AIP Conference Proceedings 1940(1), 020070-1-020070-5. doi:10.1063/1.5027985

Msarah, M., Ibrahim, I., \& Aqma, W.S. (2018). Isolation of thermophilic bacteria producing extracellular enzyme from Sungai Klah Hot Spring, Malaysia. Malaysian Applied Biology, 47(5), 269-275.

Niu, D., Zuo, Z., Shi, G. Y., \& Wang, Z. X. (2009). High yield recombinant thermostable $\alpha$-amylase production using an improved Bacillus licheniformis system. Microbial Cell Factories, 8(1), 4-7. doi:10.1186/1475$2859-8-58$

Oyeleke, S. B., \& Oduwole, A. A. (2009). Production of amylase by bacteria isolated from a cassava waste dumpsite. African Journal Microbiology, 3(4), 143-146. 
Panosyan, H., Margaryan, A., \& Birkeland, N. K. (2020). Geothermal springs in Armenia and NagornoKarabakh: potential sources of hydrolase-producing thermophilic bacilli. Extremophiles, 24, 519-536. doi:10.1007/s00792-020-01173-1

Samsudin A. R, Hamzah, U, Rahman, R. A, Siwar, C, Jani, M. F. M., \& Othman, R. (1997). Thermal springs of Malaysia and their potential development. Journal of Asian Earth Sciences, 15(2-3), 275-284. doi:10.1016/ s1367-9120(97)00012-6

Teodoro, C. E. D. S., \& Martins, M. L. L. (2000). Culture conditions for the production of thermostable amylase by Bacillus sp. Brazilian Journal of Microbiology, 31(4), 298-302. doi:10.1590/s151783822000000400011

Thippeswamy, S., Girigowda, K., \& Mulimani, V. H. (2006). Isolation and identification of alpha amylase producing Bacillus sp. from dhal industry waste. Indian Journal of Biochemistry and Biophysics 43(5), 295-298.

Van Der Maarel, M. J., Van der Veen, B., Uitdehaag, J. C., Leemhuis, H., \& Dijkhuizen, L. (2002). Properties and applications of starch converting enzymes of the $\alpha$-amylase family. Journal of Biotechnology, 94(2), 137-155. doi:10.1016/s0168-1656(01)00407-2

Verma, A., Gupta, M. \& Shirkot, P. (2014). Isolation and characterisation of thermophilic bacteria in natural hot water springs of Himachal Pradesh (India). Bioscan, 9(3), 947-952.

Vidyalakshmi, R., Paranthaman, R. \& Indhumathi, J. (2009). Amylase production on submerged fermentation by Bacillus spp. World Journal of Chemistry, 4(1), 89-91. 